\title{
Excess urinary iodine concentration and thyroid dysfunction among school age children of eastern Nepal: a matter of concern
}

\author{
Man Kumar Tamang ${ }^{1 *} \mathbb{D}$, Basanta Gelal ${ }^{2}$, Binaya Tamang ${ }^{2}$, Madhab Lamsal ${ }^{2}$, David Brodie ${ }^{3}$ and Nirmal Baral ${ }^{2}$
}

\begin{abstract}
Objectives: Deficiency as well as excess dietary iodine is associated with several thyroid disorders including Grave's disease and goitre. Previously, cross sectional studies conducted among school children in Nepal showed high prevalence of iodine deficiency. In contrast, recently, few studies have revealed emerging trends of excess urinary iodine concentration in children. This paper, reports excess urinary iodine excretion and thyroid dysfunction among school age children from eastern Nepal.

Results: It was a community based cross sectional study in which we measured urinary iodine excretion levels among school age children at baseline and after educational program. The educational program consisted of audiovisual and pamphlets on thyroid health. We also screened them for thyroid function status by physical examination and measuring serum thyroid hormones. Our results show that $34.4 \%$ of the children had excess urinary iodine concentration above the WHO recommended levels. Overall, 3.2\% of the children were identified to have thyroid dysfunction. Urinary iodine concentration was significantly different between types of salt used and between salt iodine content categories.
\end{abstract}

Keywords: Urinary iodine, Salt iodine, Deficiency, Children, Thyroid, Excess, Nepal

\section{Introduction}

Iodine deficiency disorders (IDD) are still major public health problems in developing countries although significant progress has been made towards their control strategies [1]. Urinary iodine is a sensitive marker of recent dietary iodine intake but not of thyroid dysfunction. Spot urine sample is generally recommended for population based studies [2-4]. Total goitre rate in Nepal has dramatically reduced to $0.4 \%$ in 2007 from $55 \%$ in 1965 [5]. Although iodine deficiency (ID) and prevalence of goitre have been well evidenced cases, association between excess iodine intake and thyroid disease have been found [6]. Few recently conducted studies in Nepal have demonstrated increasing trends of excess urinary iodine concentration (UIC) in children [6, 7]. In addition, latest Nepal

\footnotetext{
*Correspondence: manntamang2011@gmail.com

${ }^{1}$ Rotary Club of Dharan Ghopa, B. P. Koirala Institute of Health Sciences, Dharan, Nepal

Full list of author information is available at the end of the article
}

National Micronutrient Status Survey 2016 has revealed that median urinary iodine concentration (mUIC) in 6-9 years children was above $300 \mu \mathrm{g} / \mathrm{L}$ [8]. This report along with few other studies point out possibility of chronic excess iodine intake in Nepalese children. Acute iodine excess in new-borns can cause hypothyroidism but limited data are available on the effects of chronic high intake of iodine in thyroid function [9]. The current study was aimed to assess iodine status among school age children (SAC) and correlate it with salt iodine content (SIC), type of salt used and gender of the children. Our other aim was to check improvement of urinary iodine excretion (UIE) levels after educational program.

\section{Main text Methods \\ This community based study approached 1042 SAC from twelve government schools. These schools were selected randomly from six Village Development Committees (VDC) of the Udaypur District, Province no. 1, Nepal}


such that two schools were included from each VDC. The study commenced in October 2015 and completed in July 2017. Spot urine samples and household salt samples were collected from 946 children. Blood samples were obtained from 245 children. The urine samples were used to determine UIC whereas salt samples were used to assess household SIC. The salt samples were classified as open type and packet (iodized) type. UIC was determined by the ammonium persulfate digestion microplate (APDM) method using the Sandell-Kolthoff reaction in a specially designed apparatus, sealing cassette (Hitachi, Japan) [10] in microplate format. SIC was determined by the iodometric titration method. Blood samples were analysed for thyroid hormones (free thyroxine and thyroid stimulating hormone). Thyroid stimulating hormone (TSH) and free thyroxine (fT4) were measured using the HUMAELISA kit (Human Diagnostics, Germany) following the manufacturer's manual. Thyroid function status was determined according to the reference range provided in the kit, which reported TSH $0.39-6.16 \mathrm{mIU} / \mathrm{L}$ and fT4 $0.8-2.2 \mathrm{ng} / \mathrm{dL}$. Sub clinical hypothyroidism is considered if TSH $>6.16 \mathrm{mIU} / \mathrm{L}$ with $\mathrm{fT} 4$ in the normal range whereas subclinical hyperthyroidism is considered if $\mathrm{TSH}<0.39 \mathrm{mIU} / \mathrm{L}$ with $\mathrm{fT} 4$ in the normal range. Ethical approval for this research was taken from Institutional Review Committee, B. P. Koirala Institute of Health Sciences (BPKIHS) (IRC/655/015). Informed consent was taken from school teacher, head teacher and concerned guardians before samples were collected. To compare mean difference between two groups, Mann Whitney U test was used while for comparing three groups, Kruskal Wallis test was used.

\section{Educational program}

After the baseline survey, a series of educational programs were organized targeting the schools. The educational program consisted of an awareness of iodine and thyroid through pamphlets, posters and audio-visual aids. Information on iodized salts use and its importance
Table 2 Comparison of UIC within SIC, gender and type of salt used

\begin{tabular}{llll}
\hline Variables & \multicolumn{1}{l}{ Categories } & Mean rank & p-value \\
\hline UIC & Salt iodine content (SIC) & (ppm) & $0.000^{\mathrm{a}}$ \\
& 0 & 191.02 & \\
& $<15$ & 241.54 & \\
& $>15$ & 485.43 & \\
UIC & Gender & & $0.640^{\mathrm{b}}$ \\
& Boy & 469.16 & \\
UIC & Girl & 477.47 & $0.000^{\mathrm{b}}$ \\
& Type of salt used & & \\
& Open salt & 169.79 & \\
& Packet salt & 483.52 &
\end{tabular}

a Kruskal Wallis test

${ }^{\mathrm{b}}$ Mann-whitney U test

in health was provided to the SAC. The school teachers were trained on iodine, thyroid diseases, its preliminary identification in community setting and the importance of iodized salt. These programmes were organized twice in each school. After 1 year of the educational program, we again assessed UIC in the same cohort of school children, achieving a total of 311 urine samples.

\section{Results}

Results showed that mUIC among the children at baseline was $231 \mu \mathrm{g} / \mathrm{L}$ (IQR: 156-333) which lies in the more than adequate level. We found that $9.8 \%$ of the SAC had iodine deficiency; followed by $23.5 \%$ of the SAC who had more than adequate UIC. Most importantly, $34.4 \%$ of children had excess UIC (i.e. $\geq 300 \mu \mathrm{g} / \mathrm{L}$ ). Table 1 provides the full details. Open type salt was used by $9.3 \%$ of the children while majority of them used iodized salt distributed by Salt Trading Corporation Nepal. Salt iodine content (SIC) determination showed that $11.8 \%$ of the salt samples had iodine content of $0-15 \mathrm{ppm}$ whereas $88.2 \%$ contained more than 15 PPM. As presented in Table 2, UIC was not significantly different between boys

Table 1 UIC among the school children $(n=946$, before and $n=311$ after educational program

\begin{tabular}{|c|c|c|c|c|}
\hline \multirow[t]{2}{*}{ Urinary iodine concentration (UIC) status } & \multicolumn{2}{|c|}{ Before educational program } & \multicolumn{2}{|c|}{ After educational program } \\
\hline & Frequency $(n)$ & Percentage & Frequency (n) & Percentage \\
\hline Severe ID (<20 $\mu \mathrm{g} / \mathrm{L})$ & 4 & 0.4 & 2 & 0.6 \\
\hline Mild ID (20-49 Mg/L) & 22 & 2.3 & 12 & 3.9 \\
\hline Moderate ID (50-99 g/L) & 67 & 7.1 & 47 & 15.1 \\
\hline Adequate (100-199 g/L) & 306 & 32.3 & 94 & 30.2 \\
\hline More than adequate $(200-299 \mu \mathrm{g} / \mathrm{L})$ & 222 & 23.5 & 54 & 17.4 \\
\hline Excess $(\geq 300 \mu \mathrm{g} / \mathrm{L})$ & 325 & 34.4 & 102 & 32.8 \\
\hline Total & 946 & 100 & 311 & 100 \\
\hline
\end{tabular}


and girls $(\mathrm{p}=0.64)$, but significantly different between the SIC categories $(\mathrm{p}<0.05)$ and between type of salt used $(\mathrm{p}<0.05)$. As shown in Fig. 1, 3.2\% of the SAC had thyroid dysfunction with either hypothyroidism or hyperthyroidism. The assessment of thyroid hormones revealed that $1.6 \%$ of the SAC had subclinical hyperthyroidism and one child had overt hyperthyroidism. Overt and subclinical hypothyroidisms were identified in two children and one child respectively. Further, urinary iodine measurement after the educational program revealed that the proportion of excess UIC slightly decreased to $32.8 \%$ from baseline of $34.4 \%$. After one year of educational program, mUIC in school children $(\mathrm{n}=311)$ was $201 \mu \mathrm{g} / \mathrm{L}$, having found to decrease from baseline of $231 \mu \mathrm{g} / \mathrm{L}$.

\section{Discussion}

The present study highlighted excess urinary iodine excretion levels in SAC from eastern Nepal. Sufficient sample size is one of the big strengths of our study. In addition, physical examination of the children and biochemical test further strengthen our results. Similar to our findings, two studies from Nepal have reported high prevalence of excess UIC among school children with one study reporting median UIC of $291.8 \mu \mathrm{g} / \mathrm{L}$ (IQR $181.3-411.5 \mu \mathrm{g} / \mathrm{L}[7,9]$. A survey conducted in Nepal in 2007 demonstrated mUIC of $203 \mu \mathrm{g} / \mathrm{L}$ [11]. A cross sectional study from India in 2013 found a similar mUIC of $200 \mu \mathrm{g} / \mathrm{L}$ [12]. This implies that the population is in transition phase from iodine deficiency to iodine sufficiency. The latest Iodine Global Network report has highlighted several countries around the world to be categorized as having excess iodine status in population [11].

The time has now come to monitor the iodine status at national level and adjust policies accordingly. Together with our current results, consistent findings of excess

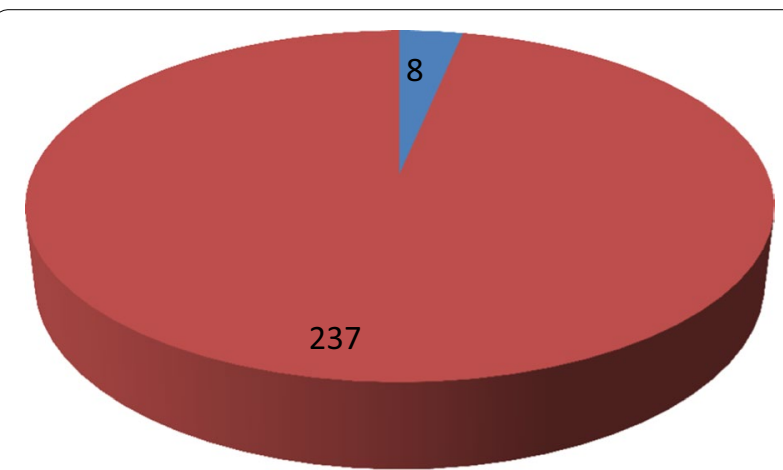

Fig. 1 Thyroid function status among the school children $(n=245)$. Blue colour shows number of school children suffering from any form of thyroid dysfunction (either hypothyroidism or hyperthyroidism). Red colour shows number of children with normal thyroid function status
UIC among school children imply chronic exposure to high dietary iodine intake. A reason for this may be due to poor awareness among SAC on the optimal consumption of iodized salt. Secondly, awareness regarding consumption of iodized salt among the households need to be improved with regard to optimal intake. In addition, poor monitoring of salt distribution and household salt consumption after initiation of salt iodization program by the government is probably a significant factor underlying this outcome. This is a matter of concern as high intake of dietary iodine could result in several thyroid disorders. This warrants a further large scale cross sectional as well as cohort studies comprising several districts to assess the iodine status of the population of the country.

\section{Conclusion}

Based on our results, we conclude that there is a high prevalence of excess urinary iodine concentration among school age children of eastern Nepal. Since almost 88\% of the household salt samples tested were found to have SIC of more than 15 PPM, we suggest the young children and their family to consume optimal salt in their diet. This may prevent them from iodine induced thyroid disorders. Also, the study recommends to explore further regarding excess iodine status in nationally representative population. Our findings suggest that programs and policies should be developed to explore and address this issue further.

\section{Limitations}

The study has a number of limitations. First, we could not collect blood samples from all the participating school children due to refusal from their parents. Second, reassessment of urinary iodine concentration after educational program could only enrol about $30 \%$ baseline population, which might limit its generalization. Third, free tri-iodothyronine (fT3) concentration was not measured in the blood samples.

\section{Abbreviations \\ UIC: urinary iodine concentration; SIC: salt iodine content; UIE: urinary iodine excretion; SAC: school age children; IDD: iodine deficiency disorder; VDC: village development committee; APDM: ammonium persulfate digestion microplate; BPKIHS: B. P. Koirala Institute of Health Sciences.}

\section{Acknowledgements}

Not applicable.

\section{Authors' contributions}

BG and NB designed the study. NB was awarded the grant. MKT, BG and BT carried out the field study, data collection and laboratory analysis. MKT, BG, $\mathrm{ML}$ and $\mathrm{DB}$ prepared the manuscript in combination. All authors read and approved the final manuscript. 


\section{Funding}

We would like to sincerely thank Rotary Foundation for the project grant (Grant Number GG1412765). The funding body had no role in design of study, data collection, analysis and interpretation of data.

\section{Availability of data and materials}

The data set used and analysed in this study are available from the corresponding author upon reasonable request.

\section{Ethics approval and consent to participate}

Ethical approval for this study was taken from Institutional Review Committee, BPKIHS (IRC/655/015). Prior written consent was taken from the guardian/ teacher before enrolling them into the study.

\section{Consent to publish}

Not applicable.

\section{Competing interests}

The authors declare that they have no competing interests.

\section{Author details}

${ }^{1}$ Rotary Club of Dharan Ghopa, B. P. Koirala Institute of Health Sciences, Dharan, Nepal. ${ }^{2}$ Department of Biochemistry, B. P. Koirala Institute of Health Sciences, Dharan, Nepal. ${ }^{3}$ Bucks New University, Slough, UK.

Received: 23 January 2019 Accepted: 22 May 2019

Published online: 27 May 2019

\section{References}

1. Zimmermann M, Jooste P, Pandav C. lodine-deficiency disorders. Lancet. 2008;372(9645):1251-62.

2. Delange F, Burgi H, Chen Z, Dunn J. World status of monitoring iodine deficiency disorders control programs. Thyroid. 2002;12(10):915-24.

3. Assessment of iodine deficiency disorders and monitoring their elimination: a guide for programme managers, 3rd edition. Geneva: World Health
Organization, International Council for Control of lodine Deficiency Disorders and UNICEF. https://www.who.int/nutrition/publications/micro nutrients/iodine_deficiency/9789241595827/en/. Accessed 5 Dec 2018.

4. Zimmermann M, Anderson M. Assessment of iodine nutrition in populations: past, present, and future. Nutr Rev. 2012;70(10):553-70.

5. Gelal B, Baral N. Moving toward the sustainable elimination of IDD in Nepal. IDD NEWSLETTER; 2010. https://www.ign.org/idd-newsletter -22010.htm. Accessed 25 Dec 2018.

6. Leung A, Braverman L. Consequences of excess iodine. Nat Rev Endocrinol. 2014;10:136-42.

7. Shakya P, Gelal B, Das B, Lamsal M, Pokharel P, Nepal A, Brodie D, Sah G, Baral N. Urinary iodine excretion and thyroid function status in school age children of hilly and plain regions of Eastern Nepal. BMC Res Notes. 2015;8:374.

8. Ministry of Health and Population, Nepal; New ERA; UNICEF; EU; USAID; and CDC. National Nepal Micronutrient Status Survey 2016. Kathmandu, Nepal. 2018. https://www.unicef.org/nepal/reports/nepal-national-micro nutrient-status-survey-report-2016. Accessed 15 Dec 2018.

9. Nepal A, Suwal R, Gautam S, Shah G, Baral N, Andersson M, Zimmermann M. Subclinical hypothyroidism and elevated thyroglobulin in infants with chronic excess iodine intake. Thyroid. 2015;25(7):851-9. https://doi. org/10.1089/thy.2015.0153.

10. Ohashi T, Yamaki M, Pandav C, Karmarkar M, Irie M. Simple microplate method for determination of urinary iodine. Clin Chem. 2000;46(4):529-36.

11. Iodine Global Network. Global Score card of lodine Nutrition in 2017 in the general population and in pregnant women (PW). IGN, Zurich, Switzerland. 2017. https://www.ign.org/scorecard.htm. Accessed 16 Dec 2018.

12. Kapil U, Pandey R, Kabra M, Jain V, Sareen N, Bhadoria A, Vijay J, Nigam S, Khenduja P. Status of iodine deficiency in district Kangra, Himachal Pradesh after 60 years of salt iodization. Eur J Clin Nutr. 2013;67:827-8.

\section{Publisher's Note}

Springer Nature remains neutral with regard to jurisdictional claims in published maps and institutional affiliations.
Ready to submit your research? Choose BMC and benefit from:

- fast, convenient online submission

- thorough peer review by experienced researchers in your field

- rapid publication on acceptance

- support for research data, including large and complex data types

- gold Open Access which fosters wider collaboration and increased citations

- maximum visibility for your research: over $100 \mathrm{M}$ website views per year

At BMC, research is always in progress.

Learn more biomedcentral.com/submissions 